\title{
White Misconducts: Informal Acts in Crossborder Primary Health Service Delivery (Case of Panggang, Central Java, Indonesia)
}

\author{
Isti Andini, Achmad Djunaedi, Deva Fosterharoldas Swasto, Ahmad Sarwadi \\ Department of Architecture and Planning, Faculty of Engineering, Universitas Gadjah Mad., Indonesia
}

\begin{abstract}
Public health services in Indonesia are managed in a territorialism approach that limits services to a specific administrative area. Refferal system in health care sets primary health facilities to each citizen and limits crossborder services. The absence of primary health care in Glagaharjo border settlement and the limitation of crossborder services created barriers for universal health care in rural provincial border settlements. Interruptions in providing services to borderland communities were a major problem with the system during the era of good governance. Informal crossborder services involving changes in health-care administration came as a viable option for ensuring universal health-care services. This paper examines the process of crossborder primary health service delivery by Pustu Panggang, Central Java Province, to communities in Glagaharjo, Daerah Istimewa Yogyakarta Province, sharing provincial borderline. Data was gathered through in-depth interviews with local officials and stakeholders. Using the compare and contrast technique, the concepts of good governance and cross-border health services are compared and contrasted. Thefindings shows that informal acts including exceeding-authority decision making, ignorance, and other forms of misconducts come as the impromptu strategy to keep primary care available to those in need. As Covid-19 pandemic unfolded, informal acts save community from the lack of access to primary healthcare due to the cost of formal arrangement.
\end{abstract}

Keywords: primary healthcare, rural border, good governance, informal, collaboration

\section{INTRODUCTION}

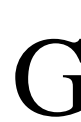
ood Governance in Decentralized Healthcare System in Indonesia

The global approach in development administration has brought Good Governance principles. Although the concepts has been dynamically developed over decades, it is still considered as a powerful approach to ensure better and more sustainable development [1],[2]. Indonesia has undergone significant shift in public administration, including decentralization of decision making process towards regional equality [3]. The introduction of a decentralized system in public administration was one of the major changes in the Indonesian public services provision system.

Good governance, along with the principles of accountability and transparency, brought an impact on the advancement of public administration in Indonesia [4]. As public administration shifting from government to governance, good governance provides a set of values to guarantee the development path is going to a more sustainable direction [5]. In a administration perspective, good governance were indicated by practices of public policy implementation that is in line with the laws [6].However, it is undeniable that the informal approach smoothes the decision-making process, shortens the time required, and, as a result, reduces the likelihood of conflict [7],[8]. An informal approach to planning ensures 'consensus' (see [9],[10])but in situation where transparency, accountability, and fairness are highly questioned. This has created a quandary in the Indonesian public administration system. Recognition of personal and informal contacts is a flagrant violation of the good governance principle.

As Reference [11] stated, Referral System is used in the provision of public health services in Indonesia. Using this referral system, health services are implemented in stages in accordance with medical needs. In this system, the population is divided into rigid service areas in order to manage the efficiency of health-care resources.In Indonesia, administrative boundaries are the sole determinant of the regional system in public services. Transfer of services for patients in different service areas necessitates changes in the patient data record that must be authorized by the authority based on the level of transfer. Authorization at the provincial level is required for resource transfers that occur at the provincial boundary, with coordination at the state level. Formalization of services takes time to ensure that public administration adheres to good governance principles, which has resulted in inefficiencies in public services and a delay in the delivery of health services.

The Panggang-Glagaharjo border area is located on Java, Indonesia's most populous island. However, the border area is quite remote, 15 kilometers in a straight line from the nearest urban center, but it took approximately 26 kilometers and 70 minutes to travel using public transportation. Glagaharjo has no primary health care center (Puskesmas); the nearest healthcare facility in the same Province of DIY is 7 kilometers away but difficult to reach due to the mountainous terrain. Panggang, on the other side of the border, has one sub-district primary health center (Pustu), which is located just across the Panggang-Glagaharjo borderline. Pustu Panggang's capacity allows for additional patients to be served.However, due to Indonesia's territorial-based healthcare system, Pustu Panggang is only permitted to serve the community within its 
administrative area. To gain access to healthcare services in a cross-border area, the system required a formal proposal from a multi-tier bureaucracy up to the country's second highest tier. In a formal arrangement, the provincial administration must acknowledge the cross-border admission. The entire process took about a month and covered more than 150 kilometers.

In Indonesia, the law governing cross-border service provision states that any resource flow must be documented and given a specific form as regional collaboration [12]. In the Indonesian public administration system, cross-border transfer of resources and services falls under regional collaboration. As reference [13] stated, Peraturan Pemerintah (Government Regulation) number 20/2020governs the formal procedures of regional collaboration in accordance with good governance principles. The eight elements of collaboration in a written agreement and the rigid stages of the collaboration process define formality. The written agreement contains eight elements: (1) the subject of collaboration, (2) the object of collaboration, (3) the scope of collaboration, (4) the rights and obligations of each party, (5) the period of collaboration, (6) the termination of the collaboration, (7) force majeure, and (8) the procedure for dispute resolution. This paper examines the misconducts that occur in the Panggang-Glagaharjo informal collaboration process, which in its implementation does not result in the loss of either party. This suggests that the misconduct is a spontaneous response from the health workforce to the system's service gap problem and the application of good governance values.

\section{METHOD AND DATA}

\section{A. $\quad$ Method}

To ensure comprehensive information on cross-border health service delivery, the data used in this paper were collected from both sides of the border. The information was gathered primarily from Pustu Panggang, the service provider, and three cross-border patients, who used the service from June 2020 to May 2021. The pandemic COVID19 condition in this border area during the observation period showed a slow dynamic, so service performance was not significantly affected by the pandemic, despite some research indicating that the pandemic has caused a crisis in primary healthcare [15]-[18].In-depth interview techniques were used to obtain data from the service provider about the process of crossborder service delivery and the motivations. An in-depth interview with the Superintendents of Pustu Panggang at Puskesmas Kemalang was conducted to validate the information. The data was then compiled in accordance with the stages of the service delivery process. Misconduct was detected using the compare-contrast technique, which compared empirical findings to formal procedures in crossborder delivery services. Motives were identified through interviews and cross-checked against the case setting to gain a comprehensive understanding of motives.As reference[14] stated in case study methods, the findings are unique to this case. Although the pattern of process and motives may arise in other cases of cross-border delivery services in Indonesia due to the similarity in case setting, generalization was not intended.

\section{B. Case Setting}

The borderland of Panggang-Glagaharjo consists of two hamlets in Panggang village and one hamlet in Glagaharjo village. The terrain in this area is hilly, with a maximum elevation difference of 30 meters. This border area is bounded on all sides by hills and cliffs, making it difficult to access services outside the border area. There are hills on the side of Sleman Regency that prevent Glagaharjo residents from accessing health services at Cangkringan. Cross-border activities are intense, with a wide range of interests, such as shopping at Panggang market, attending Glagaharjo Elementary School, or working on small-scale mining on both sides. The borderland is 7 kilometers from the nearest center in Cangkringan on the DIY with hilly terrain. The activity center in Kemalang, Jawa Tengah, is only 5 kilometers from the border, but due to the Kali Woro canyon, a detour of 10 kilometers is required. The closest center for the community in the border area is Manisrenggo in Kab. Klaten or Cangkringan in Kab. Sleman.From the perspective of the users, this collaboration was initiated because the nearest healthcare facility on the Cangkringan side was 7 kilometers away and was obstructed by hills, increasing the cost of accessing the service in a formal manner. Because Pustu Panggang is only 200 meters from Glagaharjo in the borderland, crossing the border is a viable option. From the perspective of the service provider, it was simply humanity and the health officials' code of conduct. Furthermore, the frequency of visits from Kemalang remains below the maximum service capacity. This ensures that the cross-border patient does not disrupt Pustu Panggang's performance.Figure 1 shows the map of Panggang-Glagaharjo provincial border settlement and the scheme of primary health service availability.

This collaboration occurred only at the operational level for cross-border services such as examining general diseases and disease prevention in the elderly (checking blood pressure, blood sugar and cholesterol). Puskesmas Kemalang's tactical level was aware of informal collaboration and services provided, but the information was never clearly reported. As a result, no action was taken in the area of cross-border services. The Klaten Health Office's strategic level was unaware of this collaboration, as were health officials on the user side. There were no officials involved in the service user side, both formally and informally.

This case is classified as informal collaboration based on the component because it does not meet the conditions for formal collaboration as stated in PP 28/2018. This collaboration 

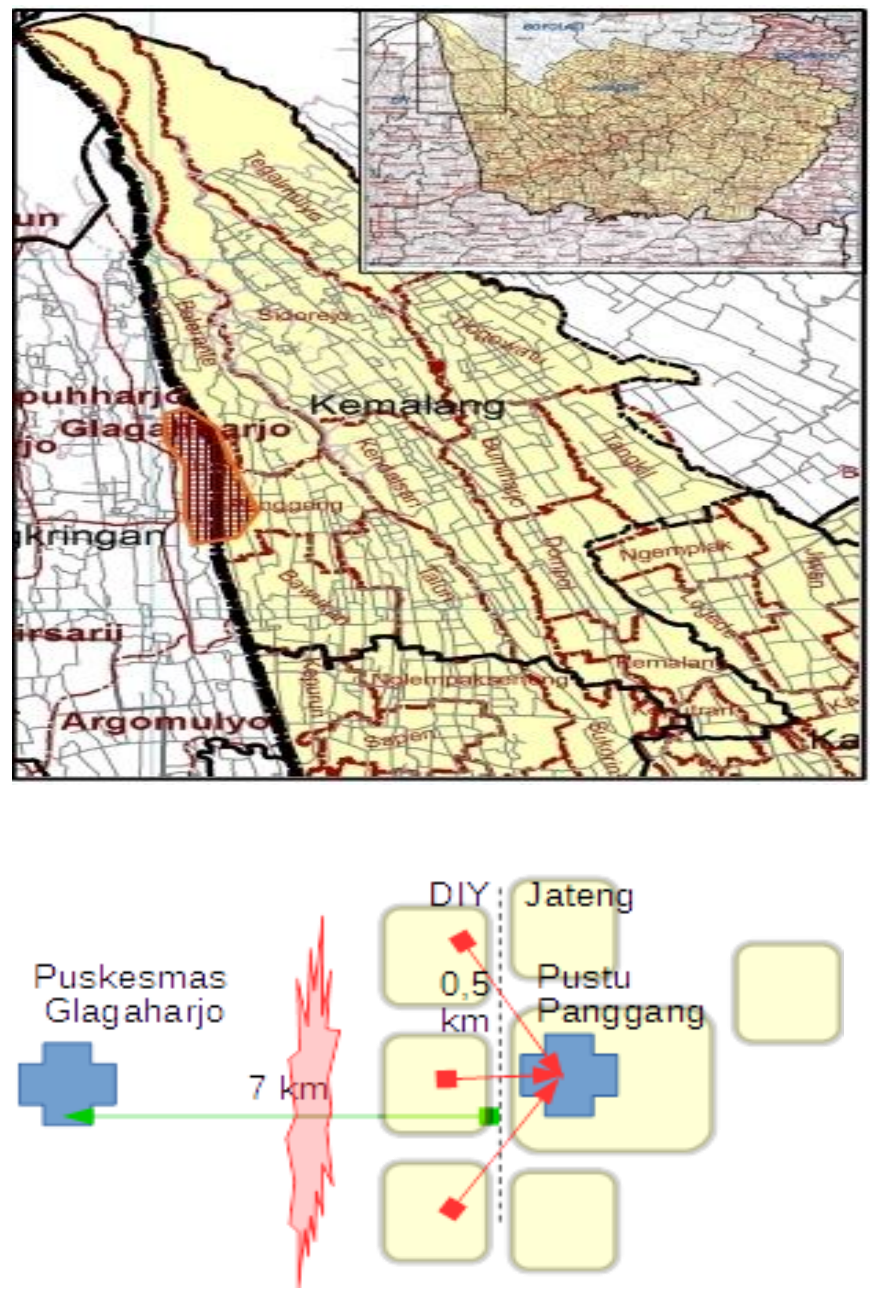

Figure 1. Panggang-Glagaharjo Provincial Border, Java, Indonesia. Green line shows formal primary healthcare delivery, red lines show informal cross border primary healthcare delivery.

Consists of only three of eight elements and has never been formally recorded. Collaboration was based on an agreement on the subject (Pustu panggang and cross-border users), the object (primary healthcare services), and the termination (when the officials transferred to another Pustu). Pustu Panggang officials modified cross-border service delivery procedures by not recording patient data in the medical record. As a result, the informality of cross-border collaboration becomes a catalyst for critical misconduct.

\section{RESULT AND DISCUSSION}

\section{A. $\quad$ Misconducts and Motives in Delivering Crossborder Primary Health Care}

In the Panggang-Glagaharjo case, the crossborder primary care has two dimensions of misconduct: collaboration arrangement misconduct and service administration misconduct. Misconducts in collaboration administration are identified in the intended termination of the formalization process and in cross-border transfer decision making. These violations occurred at the operational level during the first stage of the regional collaboration process.Requests from users should be addressed formally to Puskesmas Cangkringan, the primary health facility assigned to the Glagaharjo community. Formally, there are two ways to gain access to Pustu Panggang: request to transfer patient data from Puskesmas Cangkringan to Puskesmas Kemalang and request for regional collaboration to provide cross-border services (avoiding the need to individually transfer assigned health center). Both of these options were not taken advantage of by cross-border users.

The first misbehavior was committed by cross-border users when they interacted informally with service providers at the operational level. The motivation was the distance and time required to complete the formal procedure. Because healthcare needs are unpredictable and urgent, access time is an important determinant in selecting a service location. The second misbehavior in the collaboration process was the exercise of excessive authority in transfer decision making. The strategic level in the regional management decisionmaking chain formally owns this authority. In this case, the decision was made at the operational level by the service provider, without any notification or approval from the owner of authority. This action was motivated by humanitarian concerns as well as adherence to the health officials' code of conduct.Furthermore, cross-border services only provide local treatment, indicating that the services provided are either urgent or do not necessitate large resources. Another factor that motivates officials to act beyond their authority is the knowledge that if their actions are discovered, the consequences will be mild. As a result, after careful consideration, it was determined that the wrongdoing was worth the benefit. Table 1 depicts the misconducts and motivations for the respective misconducts in the delivery of public health services.

Table I: Misconducts and Motives

\begin{tabular}{|c|c|c|c|}
\hline Formal Procedure & Level & Misconducts & Motives \\
\hline Puskesmas Cangkringan receives patient requests formally & User to Operational staffs & $\begin{array}{c}\text { Crossborder users request } \\
\text { services personally, health } \\
\text { staffs respond directly }\end{array}$ & $\begin{array}{c}\text { Closer distance, lower } \\
\text { cost }\end{array}$ \\
\hline $\begin{array}{c}\text { Formal request of patient transfer from Kemalang Health Office } \\
\text { Formal request of collaboration in healht services from Kemalang } \\
\text { Health Office to Klaten Regency Health Office }\end{array}$ & Tactical level & Not done & $\begin{array}{c}\text { No data from operational } \\
\text { staffs }\end{array}$ \\
\hline
\end{tabular}




\begin{tabular}{|c|c|c|c|}
\hline $\begin{array}{c}\text { Collaboration request from Yogyakarta Provincial Health Office to } \\
\text { Central Java Provincial Health Office for cross-border primary health } \\
\text { services }\end{array}$ & Provincial Governments & Not done & $\begin{array}{c}\text { No request from strategic } \\
\text { level }\end{array}$ \\
\hline Collaboration negotiation and agreements & \begin{tabular}{|l|} 
Provincial Governments \\
\end{tabular} & Not done & No formal initiation \\
\hline Formalization by State Sheet Record & State & Not done & No formal collaboration \\
\hline Detailed arrangement of crossborder health services & Strategic level & Not done & No formal collaboration \\
\hline Crossborder service arrangement in Puskesmas Kemalang & Tactical level & Not done & No formal collaboration \\
\hline $\begin{array}{c}\text { Cross-border services in Pustu Panggang are provided in accordance } \\
\text { with agreements }\end{array}$ & $\begin{array}{l}\text { Operational level to } \\
\text { patients }\end{array}$ & $\begin{array}{c}\text { Done based on informal } \\
\text { agreement } \\
\text { No medical record }\end{array}$ & $\begin{array}{l}\text { Code of conduct } \\
\text { Limited resources } \\
\text { transferred }\end{array}$ \\
\hline
\end{tabular}

As the agreement was reached, misbehavior in the implementation emerged in order to maintain the informality of services. Because informal services are not recorded in the formal medical record, crossborder users do not have a medical record for every visit. There was no record of previous visits, diagnoses, or treatments. Furthermore, the absence of records was carried out in order to reduce evidence of informal cross-border services.Failure to record medical data may result in incorrect information being used as the basis for service provision. Although only a few cross-border patients were identified, the numbers may add up to a significant figure on a regional scale. This problem also demonstrates how the implementation of national policy based on assumptions and overgeneralization can be unsuitable for a specific context. The issue of informal cross-border health services may become a ticking time bomb for the nation's chaotic health information system.

\section{B. Comparison to Good Governance Principles}

As reference [19] stated, there are eight good governance principles that should be prioritized in how public services are delivered. Recent studies [20]-[22] show that assessments of governance are more appropriate when based on the services provided to citizens. One of the criticisms leveled at the concept of good governance is that indicators are difficult to meet in developing countries. According to [23], two factors shape governance: state capacity and bureaucratic autonomy. Good governance is the result of strong state service capacity and a bureaucracy with enough autonomy to respond to a variety of needs. However, in developing countries where state service capacity is limited, more stringent service standards are required to ensure that services are delivered as efficiently and effectively as possible.

The rules of implementation have covered all eight principles of good governance. As a result, cross-border health services have been formalized in order to ensure the implementation of good governance. This formal regulation, however, does not appear to be fully implemented in the case of cross-border health services in the borderland. Based on the comparison in the table above, it is clear that only three of the eight principles of good governance are being implemented. This disparity is carried out precisely in order to achieve the fundamental goals of good governance for effective public services and to reach all citizens. This case demonstrates a problem with the translation of good governance principles. Table 2 depicts the misconducts in cross border informal collaboration compared to good governance principle the implementation of good governance when it differs from its ideal.

Table II: Violation of Good Governance Principles

\begin{tabular}{|c|c|}
\hline Principles & Ideal Implementation \\
\hline Participation & $\begin{array}{l}\text { The opportunity to submit a Initiation was carried out } \\
\text { request for initiation of by the Panggang } \\
\text { collaboration } \\
\text { community, but to the } \\
\text { wrong party by } \\
\text { overstepping authority }\end{array}$ \\
\hline Rule of Law & \begin{tabular}{|l|lr}
$\begin{array}{l}\text { Procedures for cross-border } \\
\text { Cross-border }\end{array}$ & service \\
service collaboration regulated & collaboration does not \\
by laws & follow the applicable laws \\
\end{tabular} \\
\hline $\begin{array}{l}\text { Consensus } \\
\text { Oriented }\end{array}$ & $\begin{array}{l}\text { Cross-border } \\
\text { negotiations that ensure the unequally and is not } \\
\text { interests of various parties aremediated } \\
\text { accommodated }\end{array}$ \\
\hline \begin{tabular}{|l} 
Equity \\
Inclusiveness
\end{tabular} & \begin{tabular}{|l|l|}
$\begin{array}{l}\text { Cross-border services that } \\
\text { improve the quality of life and } \\
\text { do not harm either party }\end{array}$ & $\begin{array}{l}\text { improve the quality of life } \\
\text { of the people of } \\
\text { reducing the capacity of } \\
\text { services for the Panggang } \\
\text { community }\end{array}$ \\
\end{tabular} \\
\hline $\begin{array}{l}\text { Effectiveness } \\
\text { Efficiency }\end{array}$ & $\begin{array}{|lr|}\begin{array}{l}\text { Low-cost, easily accessible } \\
\text { crossborder service }\end{array} & \begin{array}{l}\text { Primary health services } \\
\text { that are easily accessible } \\
\text { and low-cost }\end{array} \\
\end{array}$ \\
\hline Accoun & \begin{tabular}{|l|l|}
$\begin{array}{l}\text { Recorded and accountable } \\
\text { cross-border services }\end{array}$ & $\begin{array}{l}\text { hross-border health } \\
\text { services are not recorded } \\
\text { and unaccountable }\end{array}$ \\
\end{tabular} \\
\hline Trans & $\begin{array}{l}\text { Open and non-discriminatory } \\
\begin{array}{l}\text { Cross-border } \\
\text { cross-border } \\
\text { information }\end{array} \\
\text { service }\end{array}$ \\
\hline Responsiveness & \begin{tabular}{|l}
$\begin{array}{l}\text { Cross-border services that can } \\
\text { serve all users }\end{array}$ \\
$\begin{array}{l}\text { Cross-border health } \\
\text { services serve outside the } \\
\text { service area }\end{array}$ \\
\end{tabular} \\
\hline Participation & $\begin{array}{l}\text { The opportunity to submit a Initiation was carried out } \\
\text { request for initiation of by the Panggang } \\
\text { collaboration } \\
\text { community, but to the } \\
\text { wrong party by } \\
\text { overstepping authority }\end{array}$ \\
\hline
\end{tabular}




\section{Borderland Dualism: Available but Not Accessible}

In assessing the availability of public services in settlements, Indonesia employs minimum service standards for settlement facilities (SPM, Standar Minimum Pelayanan). This criterion only distinguishes regions based on their urban characteristics. There is currently no SPM for distinguishing areas such as settlement areas on small islands or remote areas. As a result, the assessment of facility availability in Indonesia is urban biased. The majority of settlement agglomeration in borderland takes the form of enclaves located near a worksite or a water source. Along with the small number of service users, the mountainous terrain complicates health-care delivery.In this case, the SPM assessment revealed that the population of the border area was relatively served by primary health care facilities, but not within walking distance. The assessment of service availability ignored the pattern of agglomeration in rural border areas. According to SPM, both sides of the border in the Panggang-Glagaharjo case are statistically served by primary health care facilities. As a result, there is no formal issue with service availability. However, accessibility is a concern because the shortest path for the Glagaharjo community is approximately 7 kilometers away, with no public transportation and a mountainous topography.

When the attributes of administrative border and territorial primary health service are not taken into consideration, the accessibility for the Panggang-Glagaharjo community may be quite different. The furthest border settlement is only 2 kilometers away from Pustu Panggang. There is no physical barrier preventing the border community from visiting Pustu Panggang. The only issue with this accessibility is the administrative system of primary health care services. The service is within walking distance but is not formally accessible. The border attributesthat is considered in administrative system make primary health care facilities that are actually within easy reach turn out to be inaccessible.

D. Rules in Use: Informal Acts in Crossborder Primary Health Service

Primary health care is one of the basic services that have become mandatory for local governments in Indonesia. However, decentralization has resulted in service area segregation, which divides border areas based on administrative boundaries. Governance is a difficult task already, even without border attributes. The presence of various interests linked to a network of power and authority makes governance networks not only complicated, but also complex [24], [25]. The complexity of the network in primary health care services is related to a multi-tiered service model and limited operational autonomy. The findings show that governance networks affecting primary health services in border areas are comprised of two major networks: one in the border area (on-site) and one outside the border area (ex-site).
The complexities of the two networks differ, as do the rule of the game.

At the operational level, in-site networks include actors and decision-making processes. They interact directly with service users based on their needs. Service decisions in this network are based on complex considerations from providers and rational considerations from users. Users made the decision to make informal contact after considering the urgency of health services and comparing the costs of access, which differ significantly between formal and informal services. Service providers make the decision to provide services informally after much more thought.

Understanding regional characteristics and high access costs, backed up by sanctions that were light in comparison to the benefits of cross-border services, are determining factors in service provider decision making. This decision-making process appeared to be very subjective and individual, but it was supported by the spirit as a border community entity. The influence of other actors in this decision-making process is relatively limited in on-site networks. Borderland community development, as well as the ability to recognize available resources and devise strategies for mobilizing these resources, determine the success of community development from the inside out.

The ex-site network consists of actors and decision-making processes at the tactical and strategic levels of the health-care system. This network adheres to formal rules and keeps the health-care process contained within the formal corridor. Cross-border service providers' tactical level recognizes that if there are sufficient written reports on cross-border service requests, the process of formalizing services can begin. Despite the fact that the process is time-consuming and expensive, the ongoing formalization process can be used to justify cross-border services. The decision to keep the formal process and service formalities on the off-site network represents a fundamental mismatch between the two network.

The tactical level should be able to bridge this gap, for example, by conducting a direct inspection of the border region's health care system. This was not done due to two factors: (1) the small number of cross-border services that did not affect the capacity of services to the internal area, and (2) the possibility of additional tasks if cross-border resource transfers were formally managed. Administrative work entails a large number of levels and documents for a small number of transfers. Because of this consideration, tactical level officials have decided to wait for formal requests from operational actors.

\section{E. Informal Collaboration in Pandemic Setting}

When discussing the Covid-19 pandemic that has been occurring in Indonesia since early 2020, rural areas have a low Covid19 susceptibility characteristic due to their largely uninhabited area. Rural communities have easy access to the natural environment in their daily lives. The disease's spread rate has also been slowed due to rural isolation. According to 
[26], low-quality transportation infrastructure has reduced the number of infections. Another study by [27] identified rural isolation as a natural quarantine.On the other hand, the late 2009 Influenza Pandemic revealed that intimacy in indigenous communities' daily interactions contributed to a higher hospitalization rate [28]. The main challenge faced by rural borderland communities during the Covid19 era was the scarcity of public health services [29]. As reference [30] discovered, long waiting times were caused by insufficient health care and a large geographical distance, which ultimately harmed health care delivery in rural borderland.

According to this study, informal cooperation between regions in health services occurs because cross-border services are more accessible. Because of mobility constraints, administrative boundaries are more rigid than usual. Furthermore, due to limited access to technology and networks, cross-border services face service limitations. Data on three primary healthcare services show that cross-border patients did not use remote services throughout the pandemic.Face-to-face services are still used by cross-border patients, but the number is decreasing due to mobility restrictions. The weekly average decline in cross-border informal services was 50\% lower than before the pandemic. The impact of the pandemic on the informal collaboration process in primary health care was more visible in this study's primary health care facilities. The intensity of control is decreasing, and critical conditions are becoming more common, so the informal collaboration process is becoming shorter, with absolute decisions made at the operational level. Except in pandemic-related cases, coordination and consultation on cross-border services is becoming increasingly rare (most were suspects of Covid-19 which requires confirmation).Consideration for follow-up services to cross-border patients, on the other hand, is even more stringent. This is due to the fact that advanced health facilities are heavily reliant on health resources to combat the pandemic. The availability of resources for non-pandemic health services that are provided informally may take longer than before the pandemic.

\section{CONCLUSION}

Many border regions in Indonesia exhibit the same characteristics, as do the same primary health care policy context. As a result, there is a high likelihood of cross-border health services that are not in accordance with procedures and are informal at various provincial border settlement points throughout Indonesia. The misconduct in this case may jeopardize the government's role as a public manager in primary health care.In theory, there must be a role shift in governance from public administration at the operational level to public manager at the strategic level, though a careful guide is required throughout the transition [31],[32]. Tactical level should understand its role as a bridge in ensuring a smooth transition. The ignorance displayed in this case revealed government officials' lack of understanding of the role and transition.
At the same time, the implementation of good governance principles as elaborated in primary health care rules creates barriers to access to quick and low-cost health care. These obstacles can be fatal in the nature of services that are a race against time. As pandemics rolled, informal service delivery became more important in ensuring public health service delivery in every part of the country. Localized action results in a smaller bubble per person and faster treatment, lowering the spread and making the borderland community safer.The case demonstrated that violations of good governance principles are required in the context of cross-border services, as in this case. As a result, a formulation of specific procedureswith a good adaptability to meet the specific needs of the borderland community is required. Reorganizing border health facilities into a different set of service areas based on settlement units (instead of administrative unit) could be a viable solution. The borderland settlement should be recognized as one settlement unit in the in-site network, even if it is divided by administrative boundaries.

Consideration of borderland characteristics should be added to the variables of workload in primary health care facilities on the ex-site network. This is a cross-sectoral and cross-regional effort that can be formalized through mandatory inter-regional cooperation. This can, however, also be developed as a distinct form of governance that is directly managed by a particular border agency, which coordinates several public services sectors at operational levels.

This study has limitations in terms of appreciating changes in the policy environment that may occur and affect the definition of informality in the future if a border management system is developed. Furthermore, given the volatile nature of health-care policies, it is critical to recognize that the findings of this study are limited to the context of provincial border areas with rural characteristics and high internal isolation, as well as the management of essential public services through a referral system and territorialism.

The findings indicate that at least three critical public service sectors, namely public health, public administration, and public information system, are neede to be coordinated to ensure efficient cross-border service delivery. Recommendation for the practical application of research findings is to develop a local coordination system in the relevant public sectors. This can be considered as an initiation stage toward a policy change in primary health care provision in rural provincial borderland. Gradual changes are needed to avoid the sense of instability in public service. Meanwhile, it is recommended that further studies on the valuation of the impact of informality quantitatively compare the gap between formal and informal service performance as a basis for decision making in order to better understand the magnitude of the impact of informal service delivery.

\section{REFERENCES}

[1] Wulandari, C., Budiono, P., \& Ekayani, M. (2019) Impacts of the new Decentralization Law 23/2014 to the implementation of community based forest management in Lampung Province 
Indonesia. IOP Conf. Series: Earth and Environmental Science Proceedings of IUFROBOGOR, Bogor, Indonesia, $29 \mathrm{Sep}-05$

[2] Thapa, G., Jhalani, M., Garcia-Saiso, S., Malata, A., RoderDeWan, S., \& Leslie, H.H. (2019). High quality health systems in the SDG era: Country-specific priorities for improving quality of care. PLOS Medicine. 16(10): e1002946.https://doi.org/10.1371/journal.pmed.1002946

[3] Talitha, T., Firman, T., \& Hudalah, D. (2020). Welcoming two decades of decentralization in Indonesia: A regional development perspective. Territory, Politics, and Governance. 8(5). https://doi.org/10.1080/21622671.2019.1601595

[4] Bakri, M. R., \& Erliyana A. (2016). The substance of good governance principles on government decisions in Indonesia. Law and Justice in a Globalized World Proceedings of The Asia-Pacific Research in Social Sciences and Humanities, Depok, Indonesia, 79 Nov 2016 Accessed at https://library.oapen.org/bitstream/handle/20.500.12657/31101/63 8610.pdf? sequence $=1 \#$ page $=57$

[5] Dhaoui, I. (2019). Good Governance for Sustainable Development. Munich Persoanl RePEc Archive 92544 Accessed at https://mpra.ub.uni-muenchen.de/92544/

[6] Jubaedah, E., \& Wulandari, P. (2008). Kajian model pengukuran pelaksanaan Good Governance di pemerintahan daerah kabupaten/kota. Pusat Kajian dan Pendidikan dan Pelatihan Aparatur I LAN: Bandung 2008

[7] Schoeller, M., Guidi, M., \& Karagiannis, Y. (2017) Explaining informal policy-making patterns in the Eurozone crisis: decentralized bargaining and the theory of EU institutions. International Journal of Public Administration.40(14). pp. 12111222. doi: https://doi.org/10.1080/01900692.2017.1295266

[8] Ramos, V., Franco-Crespo, A., Gonzalez-Perez, L., Guerra, Y., Ramos-Galarza, C., Pazmino, P., \& Tejera, E. (2019). Analysis of organizational power networks through a holistic approach using consensus strategies. Heliyon. 5(2). doi: 10.1016/j.heliyon.2019.e01172

[9] Yuwono, T. (2016). Local good governance sustainability: Roles of civil society in Surakarta City, Indonesia. Jurnal Studi Pemerintahan. 7(2). 266-287. doi: https://doi.org/10.18196/jgp.2016.0030

[10] Ayres, S. (2020). A decentered assessment of the impact of 'informal governance' on democratic legitimacy. Public Policy and Administration, Special Issue: Decentered State. pp 1-24. doi: https://doi.org/10.1177/0952076720904991

[11] Ministry of Health Republic of Indonesia. (2010). The Minister of Health Regulation No. 1/2012

[12] Pratikno. (2005). Good governance and governability Jurnal Sosial Politik. 8(3). pp 231-248. doi: https://doi.org/10.22146/jsp.11043

[13] Republic of Indonesia. (2018). Government Regulation No. 28/2018

[14] Yin, R. (2009). Case Study Research 9th ed. California: Sage

[15] Fitts, M., Russel, D., Matthew, S., Liddle, Z., Mulholland, E., Comerford, C., \& Wakerman, J. (2020). Remote health service vulnerabilities and responses to the COVID-19 pandemic The Australian.Journal of Rural Health. 28(6). pp 613-617. doi: 10.1111/ajr.12672

[16] Rawaf, S., Allen, L., Stigler, F., Kringos, D., Yamamoto, H., \& van Well, C. and others. (2020) Lesson on the COVID-19 pandemic, for and by primary care professionals worldwide. European Journal of General Practice. 26(1) pp. 129-133. doi: https://doi.org/10.1080/13814788.2020.1820479

[17] O'Sullivan, B., Leader, J., Couch, D., \& Purnell, J. (2020). Rural pandemic preparedness: The risk, resilience and response required of primary healthcare.Risk Management and Healthcare Policy. 13. pp 1187-1194 doi: https://doi.org/10.2147/RMHP.S265610
[18] Kumar, A., Nayar, K., \& Koya, S. (2020). COVID-19: Challenges and its consequences for rural health care in India. Public Health in Practice. 1, 100009. doi: https://doi.org/10.1016/j.puhip.2020.100009

[19] UNESCAP. (2009). What is Good Governance? Retrieved from https://www.unescap.org/resources/what-good-governance (accessed 2 May 2021)

[20] Nguyen, T., Bach, T., Le, T., \& Le, C. (2017). Local governance, corruption and public service quality: Evidence from a national survey in Vietnam. International Journal of Public Sector Management. 30(2), pp 137-153. doi: https://doi.org/10.1108/IJPSM-08-2016-0128

[21] Van de Walle, S. (2018). Explaining citizen satisfaction and dissatisfaction with public services in The Palgrave handbook of public administration and management in Europe. Ongaro and Van Thiel (eds). London: Palgrave Macmillan

[22] Abdullah, W., Ahmad, N. \& Ariff, A. (2018). Combating corruption for sustainable public services in Malaysia: Smart governance matrix and corruption risk assessment. Journal of Sustainability Science and Management Special Issue. 4, pp. 1-14 Accessed at https://jssm.umt.edu.my/wpcontent/uploads/sites/51/2018/04/Journal_1.0-1.pdf\#page=11

[23] Fukuyama, F. (2016). Governance: What do we know and how do we know it?. Annual Review of Political Science. 19:6.1-6.7, DOI:10.1146/annurev-polisci-042214-044240

[24] Naveed, S., \& Salman, Y. (2021). Debate: Governance network for public service delivery-panacea or puzzle?. Public Money and Management. 41(1), pp. 14-16. doi: $10.1080 / 09540962.2020 .1719771$

[25] Christopoulos, D. (2017). Governance Networks in Politics. in Networked governance: New research perspective. Hollstein, Matiaske and Schnapp (eds) pp 55-70. Cham: Springer International Publishing

[26] Krenz, A., \& Strulik, H. (2021) The benefits of remoteness Digital mobility data, regional road infrastructure, and Covid-19 infections. German Economic Review. 22(3), pp 257-287 https://doi.org/10.1515/ger-2020-0068

[27] Diarra, I., Muna, L., \& Diarra, U. (2021) How the Islands of the South Pacific have remained relatively unscathed in the midst of the COVID-19 pandemic. J Microbiol Immunol Infect. 54(1), pp 131-132 doi: 10.1016/j.jmii.2020.06.015

[28] O’Sullivan, T., \& Bourgoin, M. (2010) Vulnerability in an Influenza Pandemic: Looking beyond medical risk. Faculty of Health Sciences University of Ottawa. Full text available at: http://icid.com/files/Marg_Pop_Influenza/Lit_Review__Vulnerability_in_Pandemic_EN.pdf

[29] de Luca, C., Tondelli, S., \& Aberg, H. (2020). The Covid-19 pandemic effects in rural areas. TEMA - Journal of Land Use, Mobility and Environment. pp 119-132. DOI: https://doi.org/10.6092/1970-9870/6844

[30] Garnelo, L., Parente, R. C. P., Puchiarelli, M. L. R., Correia, P. C., Torres, M. V., \& Herkrath, F. J. (2020) Barriers to access and organization of primary health care services for rural riverside populations in the Amazon. International Journal for Equity in Health. 19(54). DOI: https://doi.org/10.1186/s12939-020-01171-

[31] Westerink, J., Kempenaar, A., Lierop, M., Groot, S., van der Valk, A., \& van den Brink, A. (2017). The participating government: Shifting boundaries in collaborative spatial planning of urban regions. Environment and Planning C: Politics and Space. 35(1) pp. 147-168. doi: https://doi.org/10.1177/0263774X16646770

[32] Van der Wal, Z. (2020). Being a public manager in times of crisis: the art of managing stakeholders, political masters, and collaborative networks. Public Administration Review. 80(5). pp. 759-764. doi: https://doi.org/10.1111/puar.13245 